OPEN ACCESS

Edited by:

Adeniyi Gbadegesin,

University of Ibadan, Nigeria

Reviewed by:

Chaitanya Pande,

Mahatma Phule Krishi

Vidyapeeth, India

Sami Ghordoyee Milan,

University of Tehran, Iran

${ }^{*}$ Correspondence:

Israel R. Orimoloye

orimoloyeisrael@gmail.com

orcid.org/0000-0001-5058-2799

Specialty section:

This article was submitted to

Urban Agriculture

a section of the journal

Frontiers in Sustainable Food Systems

Received: 18 December 2021

Accepted: 13 January 2022

Published: 11 February 2022

Citation:

Orimoloye IR (2022) Agricultural Drought and Its Potential Impacts:

Enabling Decision-Support for Food

Security in Vulnerable Regions.

Front. Sustain. Food Syst. 6:838824.

doi: 10.3389/fsufs.2022.838824

\section{Agricultural Drought and Its Potential Impacts: Enabling Decision-Support for Food Security in Vulnerable Regions}

\author{
Israel R. Orimoloye ${ }^{1,2 *}$ \\ ${ }^{1}$ Centre for Environmental Management, University of the Free State, Bloemfontein, South Africa, ${ }^{2}$ Department of Geography \\ and Environmental Science, University of Fort Hare, Alice, South Africa
}

Increasing demand for food and environmental stressors are some of the most challenging problems that human societies face today and these have encouraged new studies to examine drought impacts on food production. Seeking to discuss these important issues in the South African context, this study analyzed the impacts of drought on food security in one of the country's largest commercial agricultural land (Free State Province). Earth observation and crop data were acquired from Application for Extracting and Exploring Analysis Ready Samples (AppEEARS) and GrainSA databases, respectively for years 2011/2012-2020/2021 over Free State Province. Two crops namely, maize and sorghum were obtained from the database and analyzed accordingly to quantify drought impacts on the two crops. The result reveals that the years 2015 and 2018 were affected by extreme drought events $(<10 \%)$ where the majority of the study area was impacted. Years 2011, 2016, 2018, and 2019 were severely affected by drought $(>30 \%)$ and impacted the agricultural sector in the study area. Findings further revealed that maize production observed the lowest recorded in the year 2014 and 2015 with about 223,600 and 119,050 tons, respectively. More so, results further showed that sorghum production recorded the lowest production in years 2019, 2016, and 2015 with about 23,600, 24,640, and 24,150 tons, in that order during the period of study. The results confirm the impacts of drought on maize and sorghum productions in the year 2015 and other years that recorded the lowest productions during drought years. This development might have impacted food security in the study area, and this outcome will enable decision-making bodies on food security to enhance improved strategy in vulnerable areas.

Keywords: agricultural drought, Earth observation data, food security, potential impacts, decision-support

\section{INTRODUCTION}

Drought's key characteristics, such as their inherently wide spatial and temporal extent, the large number of people impacted, or the massive economic loss, have caused logistic and financial challenges all over the world (Berhan et al., 2013; Enenkel et al., 2015). Droughts and associated food shortages are high on humanitarian relief groups' priority lists, and the bulk of online disaster platforms focus on disaster that strikes quickly (for instance, floods, hurricanes, earthquakes, 
or other storms) and little to no attention focus on drought and its occurrences. The difficulty of operational drought forecasting systems to produce valid predictions about the location, magnitude, and type of assistance needed in the medium to long term, i.e., several months ahead of time, is a serious flaw (Khadr, 2016; Hao et al., 2018; Kreibich et al., 2019). Even in cases where predictions were made, such as warnings of severe drought conditions in Sub-Saharan Africa (Ahmed, 2020; Fava and Vrieling, 2021), there is still a lack of response on the ground (Enenkel et al., 2015). Furthermore, large-scale drought predictions have failed in industrialized countries such as the United States (Schiermeier, 2013; Anderson et al., 2018; Daigh et al., 2018). This is exacerbated by the fact that there is no universally agreed definition of drought (Enenkel et al., 2015), and climate change impacts on global drought patterns (Enenkel et al., 2015; Salami et al., 2021), as well as global food security (Dhankher and Foyer, 2018; Purakayastha et al., 2019). Simultaneously, teleconnections must be considered, such as the impact of anomalies in sea surface temperatures on drought episodes in Sub-Saharan Africa, which have influenced the complexity of already sophisticated models and evaluations. Furthermore, because different types of drought, such as meteorological, agricultural, and hydrological, have varied socio-economic consequences, a single physically measurable drought parameter for all of these scenarios is not attainable (Orimoloye et al., 2019; Ekundayo et al., 2020, 2021).

In recent decades, significant progress has been made in sustaining global food production. Nonetheless, feeding 9.8 billion people by 2050 would be a challenge, particularly in drought-prone and arid regions of the developing world ( $\mathrm{He}$ et al., 2019). Droughts, for example, are a regular occurrence in Sub-Saharan Africa, particularly South Africa (Orimoloye et al., 2021a,b), and can be exacerbated by other variables (such as heat waves, floods, and violence; Ropo et al., 2017). Food production shocks (i.e., unexpected losses and increases in price) have been more common in all sectors including food industries during the last five decades (Cottrell et al., 2019; He et al., 2019). Extreme weather causes half of these shocks (Cottrell et al., 2019), with disproportionate effects on countries with little coping capability, such as farmers' ability to diversify food production or governments' ability to import food or provide insurance. The 2017 Kenya drought, for example, prompted a national emergency and left about 2.5 million people hungry (Gichure, 2017; He et al., 2019). The impact of increased drought risk due to climate change (Naumann et al., 2018; He et al., 2019) can be mitigated through more effective adaptation methods, measures and innovative research, which will aid progress toward achieving the second United Nations Sustainable Development Goal (SDG; i.e., zero hunger). If multiple interrelated SDG goals are to be achieved at the same time (e.g., SDG2 to ensure food security, SDG6 to ensure water security, and SDG13 to foster resilience), synchronous challenges emerge, as they interact across a range of spatial and temporal scales, resulting in diverse trade-offs, synergies, and even competing policy responses with scale-dependent impacts (Obersteiner et al., 2016; Gao and Bryan, 2017). Understanding the interactions between drought and food security is critical for policymakers and stakeholders to develop adaptation policies that effectively reduce the effects of drought on agricultural production and increase societal resilience to future drought-induced emergencies, all while meeting competing demands and enhancing environmental sustainability.

Recently, South Africa observed drought events that affected various sectors including agriculture and water resources. The National Disaster Management Center has declared a drought disaster due to the persistent drought conditions in the South African provinces including Free State Province and national resources are being mobilized to assist affected individuals including farmers (Tembile, 2021). South Africa is facing severe pressure with respect to water security due to an increased water demand with increasing population, poor planning and management of water resources, limited investment into water reservoir infrastructure, and recurring droughts over the past decade. Droughts are common in South Africa, however, in recent years there has been a trend toward more multi-year droughts. Summer rainfall time series for several portions of South Africa, particularly the Eastern Cape and neighboring KwaZulu Natal Province, show greater multi-year droughts from the late 1970's to the late 1970's than from 1950 to the late 1970's (Blamey et al., 2018). After a prolonged drought from 2015 to 2018, the Western Cape Province was named a disaster region in February 2018 (Pienaar and Boonzaaier, 2018; Orimoloye et al., 2019; Mahlalela et al., 2020). Drought disaster zones were proclaimed in the Eastern Cape and Free State provinces in 2019, following severe water shortages in several urban and rural areas (Mahlalela et al., 2020; Orimoloye et al., 2021a).

Assessing agricultural drought and its potential impacts on food security in vulnerable regions is very crucial especially in drought-prone areas. The implications of agricultural droughts on food supplies may be quantified, which helps policymakers make more sustainable agricultural decisions. It necessitates a thorough evaluation of the relationships between spatiotemporal drought fluctuations, farming systems, irrigation effects, and water resource availability. Various techniques of dealing with such issues have been reported. Survey methodology, for example, is useful for gathering first-hand information on how the drought has affected crop production and how farmers have reacted to drought (Campbell et al., 2011; Savari et al., 2021). In this paper, I, therefore, concentrate on agricultural drought impacts on food production in Free State Province South Africa. Findings from this study will enable decision support for food security in the affected areas. Despite the challenges associated with climate hazards such as drought disasters, recent technological, and methodological developments are helping to rapidly improve agricultural outputs (Balogun et al., 2020; Dyosi et al., 2021). The emergence of spacebased information is providing valuable outcomes at the high spatial and temporal resolutions with accurate maps, this can help smallholder-dominated farmers to plan for future drought events. Findings from this study can help in building greater resilience to drought and 
mitigate its scourges on agricultural sectors, societies, and economies.

\section{DATA AND METHODS}

\section{Study Area}

As presented in Figure 1, the study took place in the Free State Province of South Africa. The Republic of South Africa is divided into nine provinces, one of which is the Free State. Bloemfontein is South Africa's judicial capital and the province's largest city. In the study area, there are a few additional notable towns, predominantly mining, and agricultural communities. The province is located between $26.6^{\circ} \mathrm{S}$ and $30.7^{\circ} \mathrm{S}$ latitudes, and $24.3^{\circ} \mathrm{E}$ and $29.8^{\circ}$ E Greenwich meridian lengths. The climate of the province is mostly semi-arid, according to the Köppen climatic classification. The geography of the province is complex, with all surfaces above $1,000 \mathrm{~m}$ reaching $1,800 \mathrm{~m}$ in the north-eastern and eastern Free State. The province is divided into five municipal districts for administrative purposes (Fezile Dabi, Lejweleputswa, Motheo, Thabo Mofutsanyane and Xhariep). However, in November, December, and January, the region enjoys monthly mean sunlight hours of around 319.5, 296.5 , and $296.3 \mathrm{~h}$, respectively, with annual sunshine hours and total precipitation of $\sim 3,312.3$ and $559 \mathrm{~mm}$, respectively. The region receives the least amount of rain $(0 \mathrm{~mm})$ in July and the most amount of rain $(70 \mathrm{~mm})$ in January, which correspond to the winter and summer seasons, respectively (Orimoloye et al., 2021b). In June, daily mean temperatures vary from 17 to $29^{\circ} \mathrm{C}$. In January, daily mean temperatures range from 17 to $29^{\circ} \mathrm{C}$. During the months of June and July, the coldest temperatures occur at night. The vegetation dominant in the area is grassland. A better understanding of the spatiotemporal evaluation of drought events will help to identify drought-affected areas and its potential impacts on food security in the Free State Province.

\section{Data}

The Terra product from the Moderate Resolution Imaging Spectroradiometer (MODIS) was used to determine the occurrence of drought in the study area. Temperature and precipitation were acquired from NASA's Prediction of Worldwide Energy Resource database; MODIS was downloaded via the Application for Extracting and Exploring Analysis Ready Samples (AppEEARS; Abdi et al., 2019; AppEEARS Team., 2020). The MODIS instrument is used by both the Terra and Aqua missions. It has a $2,330 \mathrm{~km}$ viewing swath and views the whole Earth's surface every 1-2 days. Its detectors collect data with three spatial resolutions of 250,500 , and $1,000 \mathrm{~m}$ and measure 36 spectral bands between 0.405 and $14.385 \mathrm{~m}$. MODIS data, along with data from other sensors aboard the Terra and Aqua satellites, is relayed to ground stations via the Tracking and Data Relay Satellite System (TDRSS). The data will subsequently be forwarded to the EOS (Earth Observing System) Data and Operations System at Goddard Space Flight Center (EDOS; AppEEARS Team., 2020; Hu, 2020). The MODIS Adaptive Processing System (MODAPS) produces level 1A, level $1 \mathrm{~B}$, geolocation, and cloud mask products, as well as high-level MODIS land surface and atmosphere products, which are divided into three DAACs (Distributed Active Archive Centers) for distribution to the research and application community (Sundaresan et al., 2014). The MODIS direct broadcast signal can be used to gather regional data directly from the satellite by users with a compatible $\mathrm{x}$-band receiving device. The data (MOD13Q1 and the layers of interest: EVI and pixel reliability) was requested using an area sample, and the output was configured as GeoTIFF with geographic projection (Kring, 2007; Sundaresan et al., 2014). The VIs were created at 16-day intervals, with low-quality data removed using a MODIS-specific compositing process based on product QA. The Pixel Reliability Quality Assurance (QA) layer of MOD13Q1 was used to mask or correct pixels affected by atmospheric disturbances such as clouds. The layer classifies the efficiency of the vegetation index from -1 to 5 , although for this analysis, good, and poor values are classed as 0 and 1 , respectively. In the pixel reliability bands, poor and marginal data are accepted as acceptable accuracy and were considered for the investigation. Agricultural information was acquired from GrainSA database.

\section{Methods}

The drought conditions in the region were determined using the Vegetation Condition Index (VCI) based on the relative Normalized Vegetation Difference Index (NDVI) modification with regard to the minimum historical NDVI value as indicated by Kogan (1995). As a result, the VCI compares the current Vegetation Index (VI), such as the NDVI or the Enhanced Vegetation Index (EVI), to the values found inside a given pixel in past years during the same time period. The VCI was calculated using Equation 1 as shown below.

$$
V C I_{I J K}=\frac{V I_{I J K}-V I_{i, \min }}{V I_{i, \max }-V I_{i, \min }} \times 100
$$

where $\mathrm{VCI}_{\mathrm{ijk}}$ is the VCI value for the pixel $\mathrm{i}$ during week/month/ day of the years $\left(\mathrm{DOY}_{\mathrm{j}}\right.$ ) for year ${ }_{\mathrm{k}}, \mathrm{VI}_{\mathrm{ijk}}$ is the weekly/monthly/DOYs VI value for pixel $_{i}$ in week/month/DOY j for year ${ }_{k}$ whereby both the NDVI or EVI can be utilized as VI, $\mathrm{VI}_{\mathrm{i}}$, min and $\mathrm{VI}_{\mathrm{i}, \max }$ is the multiyear minimum and maximum VI, respectively, for pixel ${ }_{i}$.

The resulting percentage of the measured VI value in previous years was placed in the middle of the two extremes (minimum and maximum). As a result, lower and higher values indicate poor and good drought conditions, respectively. The method utilized in this study, namely, estimating drought occurrences with VCI using R programming, is based on EVI, which has several key values or benefits over other vegetative indices, such as NDVI. First, no reflected light distortions are caused by airborne particles; second, no reflected light distortions caused by ground cover vegetation. Adapted from UN-SPIDER recommended practices (http://www.unspider. org/advisory-support/recommended-practices/recommendedpractice-drought-monitoring), Figure 2 shows the planning, pre-processing, and data processing operations. Maize and sorghum yields were analyzed using Microsoft excel to identify their trends and also determine the potential impacts of drought on crop yields. 


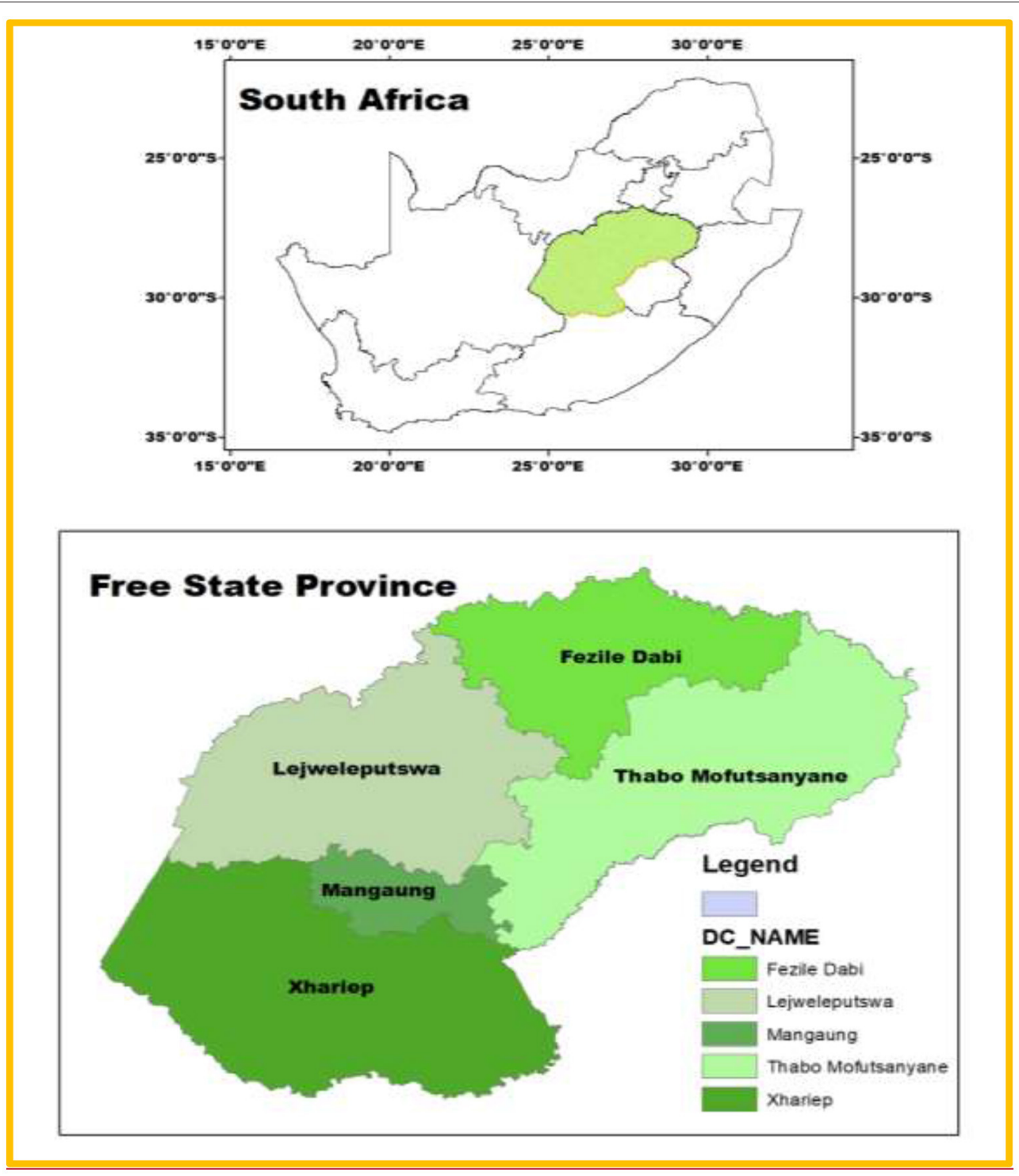

FIGURE 1 | Map of the study area.

\section{RESULTS}

Evaluation of drought events and its potential impacts on food production Free State Province has been presented in this study. Results reveal that drought patterns and severity varied from one place to another, which shows that the impacts can be varied especially on agricultural sector between the years 2011 and 2020. Information in Figure 3 presents drought episodes over the study area for the period of study using space-based information to quantify drought potential impacts on food security in the affected areas. From the findings, it was noted that the year 2015 and 2018 were extremely affected by drought events, this connotes that the affected years would have been impacted in terms of food production and other water-reliant sectors. It has been noted previously that there is a significant increase in mild drought events in the Free State Province, from shorter time steps (first decade) to longer time steps (third decade; Botai et al., 2016). During the year 2015, the Free State Province appears to have had more droughts. Drought categories have substantial implications for a variety of sectors, including agriculture and water. According to a study, drought reduced agricultural productivity in South Africa by $8.4 \%$ in 2015. The livestock industry, for example, had a $15 \%$ drop in national herd stock as a result of the drought (Matlou et al., 2021). The result further reveals that years 2017 was severely affected by drought where some areas are more impacted than others. This variability may be due to several factors, such as topography, rainfall amount, human and natural activities (Ayanlade et al., 2018). Drought periods affect the agricultural sector the most compared to other sectors (mining, manufacturing, construction, 


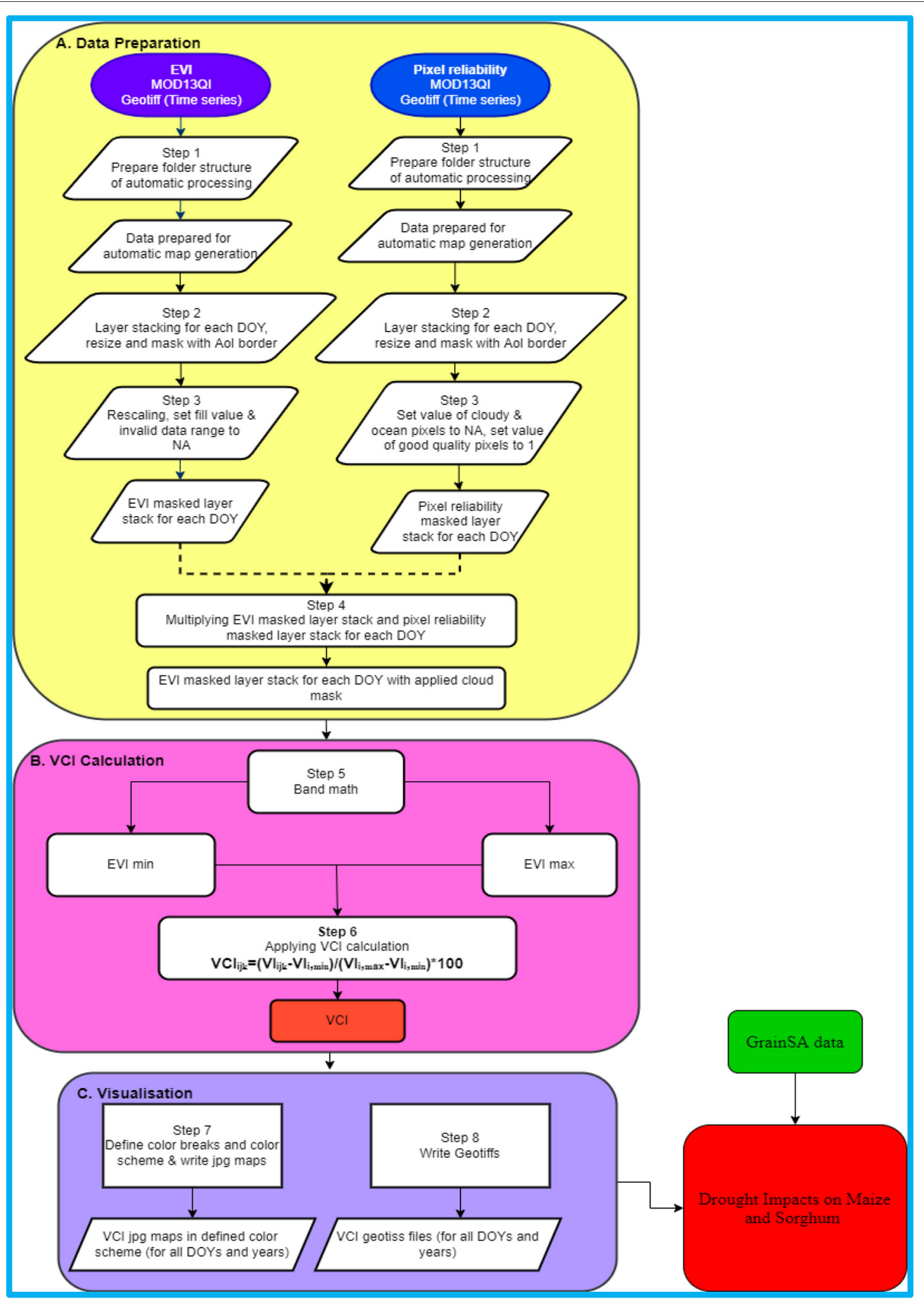

FIGURE 2 | Flow chart. 


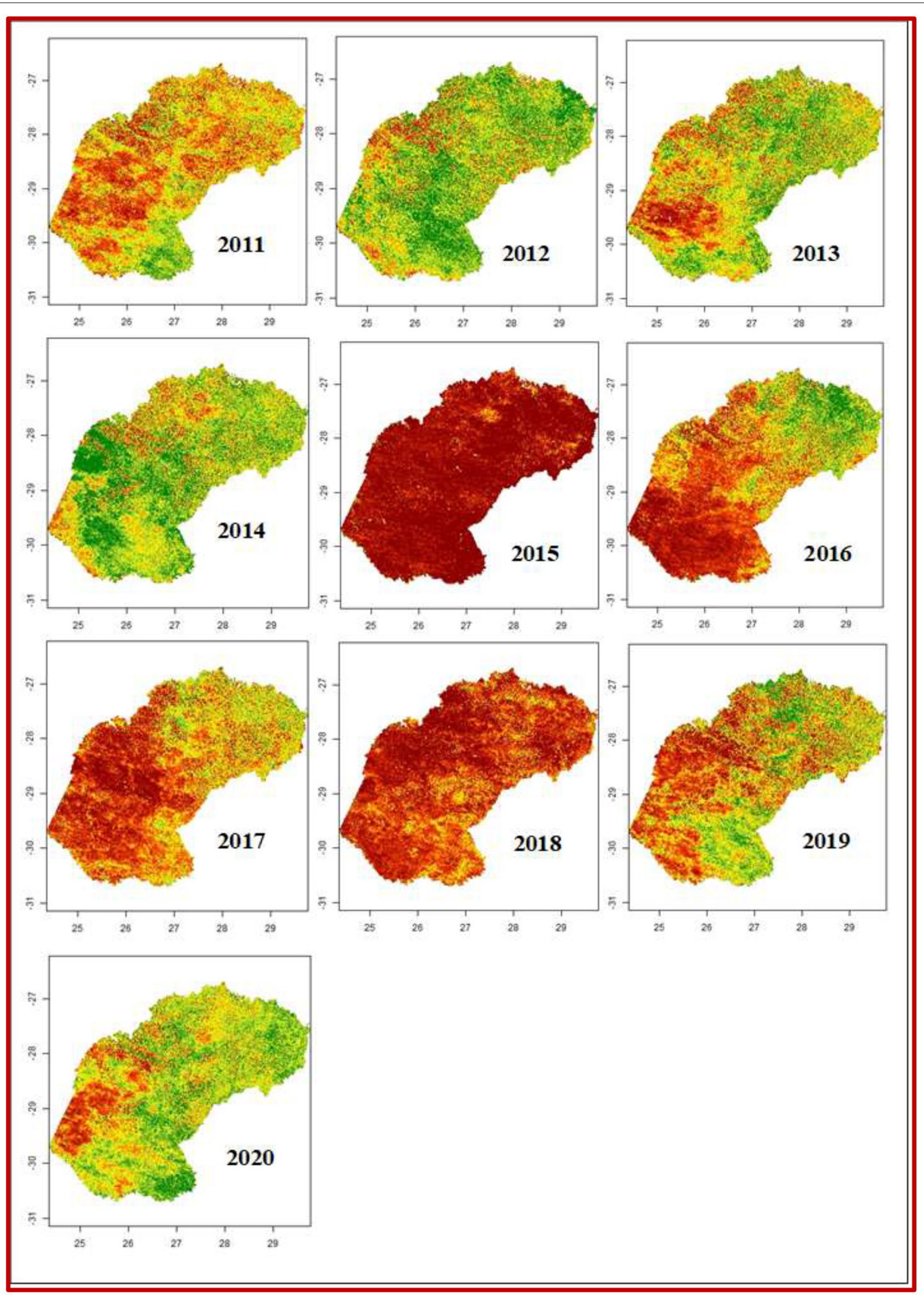

FIGURE 3 | Drought events for the year 2011-2020. 
trade, transport, finance, and community service; Matlou et al., 2021).

Years 2011 and 2019 were moderately affected by drought as presented in Figure 3 and Table 1. Farmers may lose resources such as capital if drought damages their crops during these years. If the farmers water supply is insufficient, they may be forced to spend more money on irrigation or drill more wells, or produce lower yields during the affected years (Baudoin et al., 2017; Kuwayama et al., 2019). Ranchers may have to pay more money on livestock feed and water. Results further reveal that years 2012 and 2014 observed no drought episodes which connote that these 2 years may not be directly affected by drought except the prolonged drought events from the previous years (Nguyen et al., 2018). Extreme climate events, including prolonged drought, may establish long-lasting effects on soil biotic and abiotic properties, thus influencing ecosystem functions including primary productivity in subsequent years (Nguyen et al., 2018).

Information in Figures 4, 5 present agricultural productions between year 2011 and 2020 for maize and sorghum productions, respectively. Since agricultural drought is caused by belowaverage precipitation and/or above-average temperatures and wind, which evaporate moisture from soils and plants, this in turn influences crops yield (Madadgar et al., 2017; Leng and Hall, 2019; Orimoloye et al., 2021d). The study area recorded the lowest maize yield in year 2015 with about 1191 tons, followed by year 2014 with about 2,236 tons. The lowest maize production recorded in year 2015 corroborates with the extreme drought event in the same year (Figure 3 and Table 1). The primary direct economic impact of drought in the agricultural sector is crop failure and pasture losses and this can severely affect income (Madadgar et al., 2017; Liu et al., 2018; Leng and Hall, 2019; Orimoloye et al., 2021a,c). Findings further reveal that years 2016, 2019, and 2020 recorded 5,110, 4,700, and 4,492 tons, respectively. This is further supported by drought evaluations where these 3 years observed moderate drought episodes, this may also be influenced by the drought events. Studies have shown that yield loss risk tends to grow faster when experiencing a shift in drought severity from moderate to severe conditions (Leng and Hall, 2019; Orimoloye et al., 2021a,d). This analysis shows that variability in drought trends plays an important role in determining drought impacts, through reducing or amplifying drought-driven yield loss risk (Leng and Hall, 2019).

Sorghum production between year 2011 and 2020 is presented in Figure 4. Total average yield ( $/$ ha) for sorghum show that 0.9 (2016), 1.3 (2015), and 2.2 (2013) were recorded in the study area. Year 2013 recorded 139,200 tons of sorghum yields while years 2015,2016 , and 2018 recorded the lowest sorghum production with about $24,150,24,640$, and 23,600 , respectively during the period (Figure 4).

\section{DISCUSSION}

Drought is an extreme stage of the hydrological cycle that occurs when water availability is lower than typical (Orimoloye et al., 2019; Adedeji et al., 2020). Droughts typically begin with a lack of precipitation (meteorological drought), which can be aggravated by increased evapotranspiration owing to high temperatures, which can spread to the land surface and result in reduced soil moisture (agricultural drought) and streamflow (called hydrological drought). Water stress during drought slows down crop root growth, delays maturation and reduces agricultural productivity (Ge et al., 2012; Piscitelli et al., 2021). Drought occurrence is critical because crop yield susceptibility to water stress varies by development stage, which is linked to the fundamental biophysical principles of crop growth (Oliveira and Araújo, 2021). As a result, drought impacts on agricultural productivity must be assessed independently for particular growth stages, which is more relevant for agricultural water management (Orimoloye et al., 2021d). Space-based assessments of drought are important tools for estimating drought impacts on crop yields (Derese et al., 2018; Orimoloye et al., 2021c) but these are inherently scale-dependent, ranging from the farm level at the local level to the global scale. This highlights the need for space-based information approaches (Orimoloye et al., 2021c) to simultaneously consider the joint distribution of the spatial and temporal footprint of drought. Such approaches can be combined with model-based large ensembles for more robust quantification of agricultural risk, this can also consider whether risk assessments are transferable across scales.

Drought tolerance may arise from extra copies of key genes, and sorghum's efficient photosynthetic pathway may be cobbled together from existing photosynthetic genes and duplicated genes that shifted their function over millions of years in order to withstand drought episodes (Citations). Droughts in the study area, infestation, insects, birds, and diseases, a lack of varieties with farmers' preferred traits and high yield potential, limited policy support, a lack of improved seed system, poor sorghum production practices and crop input application, and poor soil fertility may all have contributed to the decline in sorghum productivity (Derese et al., 2018). Among the sorghum production constraints listed, severe drought in the post-flowering stage may be the most significant over time. A large number of farmers in the affected area may need to produce medium-maturing sorghum cultivars with high grain and biomass yields that can be planted at normal planting times yet avoid post-flowering drought (Azu et al., 2021; Abreha et al., 2022).

Analysis from this study revealed spatio-temporal distributions of drought and crop trends over the study area (Table 1). From the findings, drought event implications on agricultural products were identified, it was noted that the years that experienced drought episodes witnessed a decline in crop yields. For instance, the year 2015 observed extreme drought, both crops explored in the study experienced a drop in their yields, this also repeated in the year 2018 with potential drought impacts on agricultural productions (Madadgar et al., 2017; Liu et al., 2018; Leng and Hall, 2019). Persistent drought episodes can influence food insecurity as this has been recorded in previous studies (Cottrell et al., 2019; He et al., 2019). This can sometimes cause problems for downstream agriculture, particularly when the growing season for crops and peak food demand periods do 
TABLE 1 | Potential drought impacts on agricultural products between 2011 and 2020.

\begin{tabular}{lll}
\cline { 3 - 3 } & \multicolumn{2}{c}{ (Drought and agricultural production between 2011 and 2020) } \\
\cline { 2 - 3 } & Drought & Maize \\
\hline 2011 & & \\
2012 & & \\
2013 & & \\
2014 & & \\
2015 & & \\
2016 & & \\
2017 & & \\
2018 & & \\
2019 & & \\
2020 & & \\
\hline
\end{tabular}

Drought; Green, no drought; Yellow, moderate/severe; Red, extreme drought.

Agricultural production; Green boxes, increase; Red boxes, decrease, white, no data.

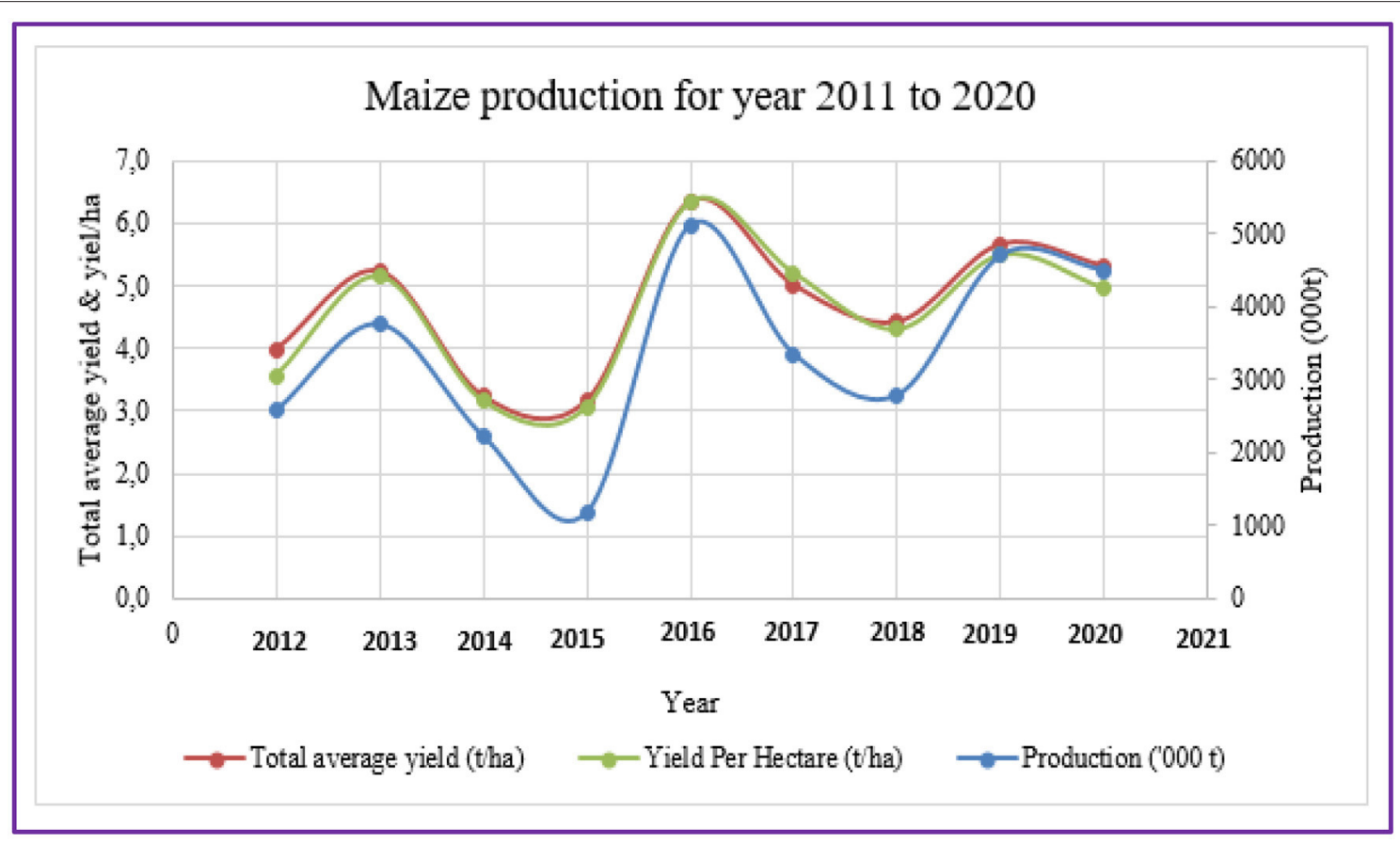

FIGURE 4 | Maize for year 2011-2020.

not coincide. The amount to which trade-offs exist, however, is determined by the duration and spatial footprint of droughts.

\section{Improved Decision-Support for}

\section{Agricultural Droughts in Vulnerable Region} There are a number of new technological developments that could support drought risk reduction. Here we will focus on space-based information that could be better integrated to improve decision-support especially in combatting drought disasters. The approach used in this study will improve agricultural drought monitoring in the drought-affected area
(Enenkel et al., 2015; Brandt et al., 2017). This will help in gaining a better understanding of the uncertainty of long-term drought forecasts and how this information can be integrated with satellite-derived soil moisture and its potential influence on food security. For example, year 2015 observed extreme drought where both crops explored in the study observed declined in productions, this also repeated in the year 2018 with potential drought impacts on agricultural productions. These years can be examined to know how drought events have affected the area especially, agricultural production and to suggest possible practices to avert future occurrence. More so, integration of 


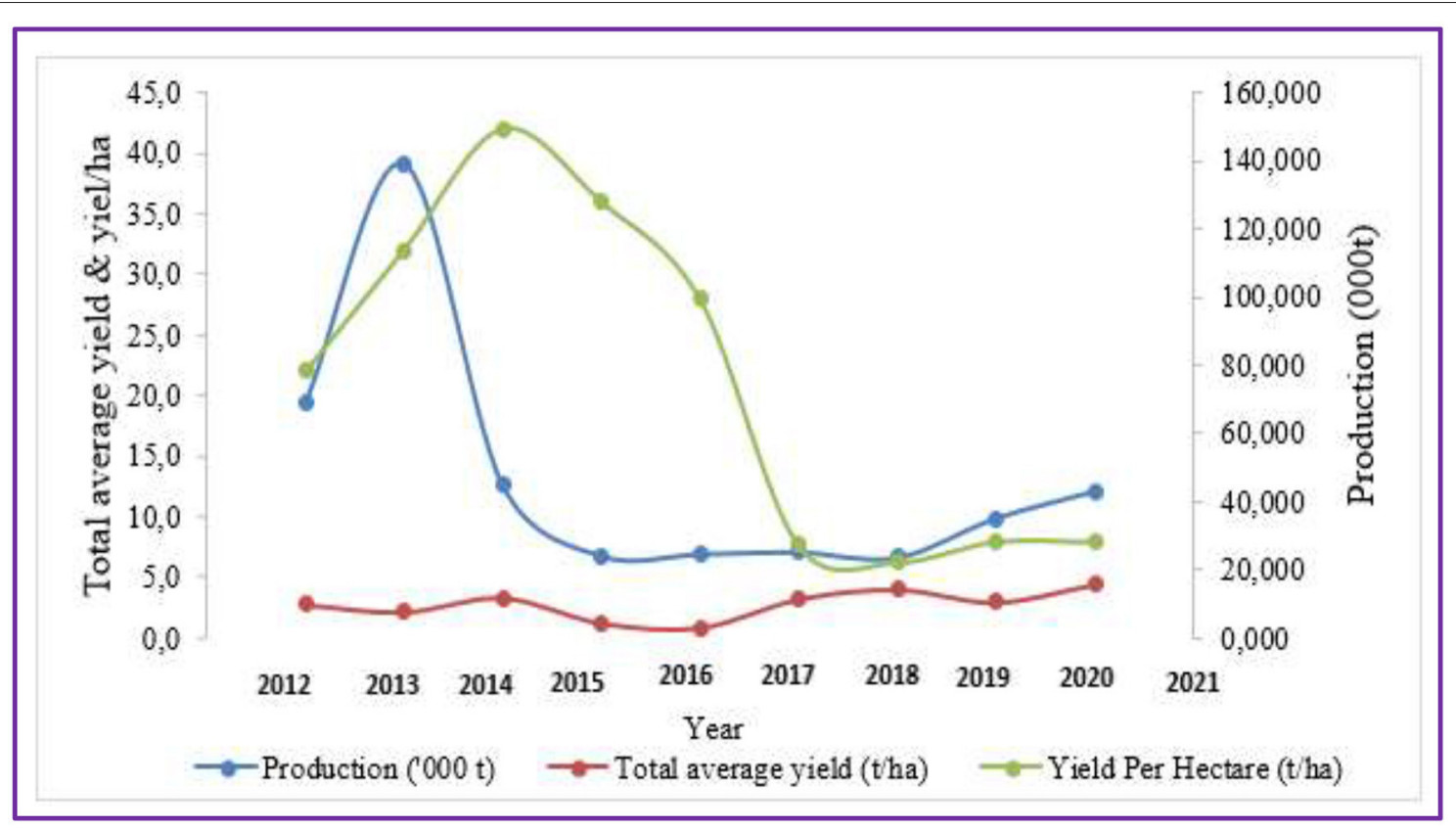

FIGURE 5 | Sorghum for year 2011-2020.

non-environmental information that can contribute to drought impact may be considered.

The most important question is: what can science do to help people make better decisions regarding drought hazards? The integrated and modification of existing technologies, including various satellite-based systems and people's experiences, is one logical and promising option. Organizations like AppEEARS (Application for Extracting and Exploring Analysis Ready Samples), USGS (United States Geological Survey), EUMETSAT (European Organization for the Exploitation of Meteorological Satellites), and NOAA (National Oceanic and Atmospheric Administration) provide a wide range of satellite-derived datasets that are operational, near real-time, and free of charge (or with a minimal and low-cost receiving station). Datasets obtained from sensors, in addition to some of the more regularly used remote sensing products, can be delivered at a spatial resolution that is worth considering to complement or replace in-situ observations. Local measurement flaws including inadequate coverage and lack of spatial consistency are frequently compensated for using these databases. The interaction of drought-inducing main climatic elements (rainfall, temperature, soil moisture, evapotranspiration, and vegetation) is reasonably well-understood (Enenkel et al., 2015; Afuye et al., 2021a,b). One key issue is that large-scale planning necessitates accurate drought forecasts several months in advance, which are currently insufficient (Yaseen and Shahid, 2021). Another concern is that agricultural drought is only one of several potential causes of food insecurity. High degrees of vulnerability induced by interacting socio-economic factors, such as political turmoil and rising or fluctuating food costs, often encourage famine. In fact, the methods for monitoring environmental anomalies and their socioeconomic consequences are hardly comparable. Researchers should engage more closely with end-users in a multi-disciplinary manner in order to establish a holistic drought monitoring system. This strategy will help by identifying the current weak links and suggesting future mitigation strategies.

\section{CONCLUSION}

This study presented agricultural drought and its potential impacts in order to enable decision-support for food security in vulnerable societies. Analysis from this study revealed spatiotemporal distributions of drought and crop trends over the study area. The outcomes from this study revealed drought event implications on agricultural products, it was also noted that the years that experienced drought episodes witnessed a decline in crop yields. For example, year 2015 observed extreme drought, both crops explored in the study experienced a decrease in agricultural productions, this was also repeated in the year 2018 with potential drought impacts on agricultural productions during the same period. The consequence of drought is a translation of failure of early warning, local action, disaster preparedness and lack of external support. The approach for monitoring drought anomalies and their agricultural impact is hardly comparable. Scientists should engage more closely with the affected parties (farmers and water-reliant sectors), end-users in a multi-disciplinary manner in order to establish a holistic drought monitoring system. This strategy will help by identifying the current weak links and suggesting future mitigation strategies. Consequently, it is necessary to appraise drought disasters by incorporating climate information, environmental and economic implications of drought in the study area and the surrounding environments, this will help in identifying the contributing factors and the actual impacts of its occurrences in the region. 


\section{DATA AVAILABILITY STATEMENT}

The raw data supporting the conclusions of this article will be made available by the authors, without undue reservation.

\section{REFERENCES}

Abdi, O., Shirvani, Z., and Buchroithner, M. F. (2019). Forest drought-induced diversity of Hyrcanian individual-tree mortality affected by meteorological and hydrological droughts by analyzing moderate resolution imaging spectroradiometer products and spatial autoregressive models over northeast Iran. Agri. For. Meteorol. 275, 265-276. doi: 10.1016/j.agrformet.2019.05.029

Abreha, K. B., Enyew, M., Carlsson, A. S., Vetukuri, R. R., Feyissa, T., Motlhaodi, T., et al. (2022). Sorghum in dryland: morphological, physiological, and molecular responses of sorghum under drought stress. Planta 255, 1-23. doi: 10.1007/s00425-021-03799-7

Adedeji, O., Olusola, A., James, G., Shaba, H. A., Orimoloye, I. R., Singh, S. K., et al. (2020). Early warning systems development for agricultural drought assessment in Nigeria. Environ. Monit. Assess. 192, 1-21. doi: 10.1007/s10661-020-08730-3

Afuye, G. A., Kalumba, A. M., Busayo, E. T., and Orimoloye, I. R. (2021a). A bibliometric review of vegetation response to climate change. Environ. Sci. Poll. Res. 7, 1-13. doi: 10.1007/s11356-021-16319-7

Afuye, G. A., Kalumba, A. M., and Orimoloye, I. R. (2021b). Characterisation of vegetation response to climate change: a review. Sustainability 13:7265. doi: $10.3390 /$ su13137265

Ahmed, S. M. (2020). Impacts of drought, food security policy and climate change on performance of irrigation schemes in Sub-saharan Africa: the case of Sudan. Agri. Water Manag. 232:106064. doi: 10.1016/j.agwat.2020.106064

Anderson, G. J., Lucas, D. D., and Bonfils, C. (2018). Uncertainty analysis of simulations of the turn-of-the-century drought in the Western United States. J. Geophys. Res. Atmos. 123, 13-219. doi: 10.1029/2017JD027824

AppEEARS Team. (2020). Application for Extracting and Exploring Analysis Ready Samples (AppEEARS). Ver. 2.44. Sioux Falls, SD: NASA EOSDIS Land Processes Distributed Active Archive Center (LP DAAC), USGS/Earth Resources Observation and Science (EROS) Center. Available online at: https:// lpdaacsvc.cr.usgs.gov/appeears (accessed June 2021).

Ayanlade, A., Radeny, M., Morton, J. F., and Muchaba, T. (2018). Rainfall variability and drought characteristics in two agro-climatic zones: an assessment of climate change challenges in Africa. Sci. Tot. Environ. 630, 728-737. doi: 10.1016/j.scitotenv.2018.02.196

Azu, E., Elegba, W., Asare, A. T., Blege, P. K., Amoatey, H. M., and Danquah, E. Y. (2021). Responses of smallholder farmers on sorghum production preferences and constraints in the Upper East Region of Ghana. J. Agri. Extens. Rural Dev. 13, 202-216. doi: 10.5897/JAERD2021.1260

Balogun, A. L., Marks, D., Sharma, R., Shekhar, H., Balmes, C., Maheng, D., et al. (2020). Assessing the potentials of digitalization as a tool for climate change adaptation and sustainable development in urban centres. Sustain. Cities Soc. 53:101888. doi: 10.1016/j.scs.2019.101888

Baudoin, M. A., Vogel, C., Nortje, K., and Naik, M. (2017). Living with drought in South Africa: lessons learnt from the recent El Niño drought period. Int. J. Disast. Risk Reduct. 23, 128-137. doi: 10.1016/j.ijdrr.2017.05.005

Berhan, G., Hill, S., Tadesse, T., and Atnafu, S. (2013). Drought prediction system for improved climate change mitigation. IEEE Trans. Geosci. Remote Sens. 52, 4032-4037. doi: 10.1109/TGRS.2013.2279020

Blamey, R. C., Kolusu, S. R., Mahlalela, P., Todd, M. C., and Reason, C. J. C. (2018). The role of regional circulation features in regulating El Niño climate impacts over southern Africa: a comparison of the 2015/2016 drought with previous events. Int. J. Climatol. 38, 4276-4295. doi: 10.1002/joc.5668

Botai, C. M., Botai, J. O., Dlamini, L. C., Zwane, N. S., and Phaduli, E. (2016). Characteristics of droughts in South Africa: a case study of free state and North West Provinces. Water 8:439. doi: 10.3390/w8100439

Brandt, P., Kvakić, M., Butterbach-Bahl, K., and Rufino, M. C. (2017). How to target climate-smart agriculture? Concept and application of the consensusdriven decision support framework "targetCSA". Agri. Syst. 151, 234-245. doi: 10.1016/j.agsy.2015.12.011

\section{AUTHOR CONTRIBUTIONS}

The author confirms being the sole contributor of this work and has approved it for publication.

Campbell, D., Barker, D., and McGregor, D. (2011). Dealing with drought: small farmers and environmental hazards in southern St. Elizabeth, Jamaica. Appl. Geogr. 31, 146-158. doi: 10.1016/j.apgeog.2010.03.007

Cottrell, R. S., Nash, K. L., Halpern, B. S., Remenyi, T. A., Corney, S. P., Fleming, A., et al. (2019). Food production shocks across land and sea. Nat. Sustainabil. 2, 130-137. doi: 10.1038/s41893-018-0210-1

Daigh, A. L., Dick, W. A., Helmers, M. J., Lal, R., Lauer, J. G., Nafziger, E., et al. (2018). Yields and yield stability of no-till and chisel-plow fields in the Midwestern US Corn Belt. Field Crops Res. 218, 243-253. doi: $10.1016 /$ j.fcr.2017.04.002

Derese, S. A., Shimelis, H., Laing, M., and Mengistu, F. (2018). The impact of drought on sorghum production, and farmer's varietal and trait preferences, in the north eastern Ethiopia: implications for breeding. Acta Agri. Scand. Sect. B Soil Plant Sci. 68, 424-436. doi: 10.1080/09064710.2017.14 18018

Dhankher, O. P., and Foyer, C. H. (2018). Climate Resilient Crops for Improving Global Food Security and Safety. doi: 10.1111/pce.13207

Dyosi, M., Kalumba, A. M., Magagula, H. B., Zhou, L., and Orimoloye, I. R. (2021). Drought conditions appraisal using geoinformatics and multi-influencing factors. Environ. Monitor. Assess. 193, 1-19. doi: 10.1007/s10661-021-0 9126-7

Ekundayo, O. Y., Okogbue, E. C., Akinluyi, F. O., Kalumba, A. M., and Orimoloye, I. R. (2020). Spatiotemporal drought assessment using vegetation health index and standardized precipitation index over Sudano-Sahelian region of Nigeria. Afri. Geogr. Rev. 2020, 1-13. doi: 10.1080/19376812.2020.1841658

Ekundayo, O. Y., Okogbue, E. C., Akinluyi, F. O., Kalumba, A. M., and Orimoloye, I. R. (2021). "Geoinformatics approach to desertification evaluationusing vegetation cover changes in the Sudano-Sahelian Region of Nigeria from 2000 to 2010," in Re-envisioning Remote Sensing Applications (Boca Raton, FL: CRC Press), 261-270. doi: 10.1201/9781003049210-18

Enenkel, M., See, L., Bonifacio, R., Boken, V., Chaney, N., Vinck, P., et al. (2015). Drought and food security-Improving decision-support via new technologies and innovative collaboration. Glob. Food Security 4, 51-55. doi: 10.1016/j.gfs.2014.08.005

Fava, F., and Vrieling, A. (2021). Earth observation for drought risk financing in pastoral systems of sub-Saharan Africa. Curr. Opin. Environ. Sustainabil. 48, 44-52. doi: 10.1016/j.cosust.2020.09.006

Gao, L., and Bryan, B. A. (2017). Finding pathways to national-scale land-sector sustainability. Nature 544, 217-222. doi: 10.1038/nature21694

Ge, T., Sui, F., Bai, L., Tong, C., and Sun, N. (2012). Effects of water stress on growth, biomass partitioning, and water-use efficiency in summer maize (Zea mays L.) throughout the growth cycle. Acta Physiol. Plant. 34, 1043-1053. doi: 10.1007/s11738-011-0901-y

Gichure, R. W. (2017). Effects of Drought on Crop Production and Coping Mechanisms Undertaken by Small Scale Farmers: a Case of Makueni County, Kenya. (Doctoral dissertation), University of Nairobi, Nairobi, Kenya.

Hao, Z., Singh, V. P., and Xia, Y. (2018). Seasonal drought prediction: advances, challenges, and future prospects. Rev. Geophys. 56, 108-141. doi: 10.1002/2016RG000549

He, X., Estes, L., Konar, M., Tian, D., Anghileri, D., Baylis, K., et al. (2019). Integrated approaches to understanding and reducing drought impact on food security across scales. Curr. Opin. Environ. Sustainabil. 40, 43-54. doi: 10.1016/j.cosust.2019.09.006

$\mathrm{Hu}, \mathrm{Z}$. (2020). Earth Observation for the Assessment of Long-Term Snow Dynamics in European Mountains-Analysing 35-Year Snowline Dynamics in Europe Based on High Resolution Earth Observation Data between 1984 and 2018. (Doctoral dissertation), Universität Würzburg, Würzburg, Germany.

Khadr, M. (2016). Forecasting of meteorological drought using Hidden Markov Model (case study: the upper Blue Nile river basin, Ethiopia). Ain Shams Eng. J. 7, 47-56. doi: 10.1016/j.asej.2015.11.005 
Kogan, F. N. (1995). Application of vegetation index and brightness temperature for drought detection. Adv. Space Res. 15, 91-100. doi: 10.1016/0273-1177(95)00079-T

Kreibich, H., Blauhut, V., Aerts, J. C., Bouwer, L. M., Van Lanen, H. A., Mejia, A., et al. (2019). How to improve attribution of changes in drought and flood impacts. Hydrol. Sci. J. 64, 1-18. doi: 10.1080/02626667.2018.1558367

Kring, D. A. (2007). Guidebook to the Geology of Barringer Meteorite Crater, Arizona (Aka Meteor Crater). (Houston: Lunar and Planetary Institute), 150.

Kuwayama, Y., Thompson, A., Bernknopf, R., Zaitchik, B., and Vail, P. (2019). Estimating the impact of drought on agriculture using the US Drought Monitor. Am. J. Agri. Econ. 101, 193-210. doi: 10.1093/ajae/aay037

Leng, G., and Hall, J. (2019). Crop yield sensitivity of global major agricultural countries to droughts and the projected changes in the future. Sci. Tot. Environ. 654, 811-821. doi: 10.1016/j.scitotenv.2018.10.434

Liu, X., Pan, Y., Zhu, X., Yang, T., Bai, J., and Sun, Z. (2018). Drought evolution and its impact on the crop yield in the North China Plain. J. Hydrol. 564, 984-996. doi: 10.1016/j.jhydrol.2018.07.077

Madadgar, S., AghaKouchak, A., Farahmand, A., and Davis, S. J. (2017). Probabilistic estimates of drought impacts on agricultural production. Geophys. Res. Lett. 44, 7799-7807. doi: 10.1002/2017GL073606

Mahlalela, P. T., Blamey, R. C., Hart, N. C. G., and Reason, C. J. C. (2020). Drought in the Eastern Cape region of South Africa and trends in rainfall characteristics. Climate Dyn. 55, 2743-2759. doi: 10.1007/s00382-020-05413-0

Matlou, R., Bahta, Y. T., Owusu-Sekyere, E., and Jordaan, H. (2021). Impact of agricultural drought resilience on the welfare of smallholder livestock farming households in the Northern Cape Province of South Africa. Land 10:562. doi: $10.3390 /$ land 10060562

Naumann, G., Alfieri, L., Wyser, K., Mentaschi, L., Betts, R. A., Carrao, H., et al. (2018). Global changes in drought conditions under different levels of warming. Geophys. Res. Lett. 45, 3285-3296. doi: 10.1002/2017GL076521

Nguyen, L. T., Osanai, Y., Lai, K., Anderson, I. C., Bange, M. P., Tissue, D. T., et al. (2018). Responses of the soil microbial community to nitrogen fertilizer regimes and historical exposure to extreme weather events: flooding or prolonged-drought. Soil Biol. Biochem. 118, 227-236. doi: 10.1016/j.soilbio.2017.12.016

Obersteiner, M., Walsh, B., Frank, S., Havlík, P., Cantele, M., Liu, J., et al. (2016). Assessing the land resource-food price nexus of the Sustainable Development Goals. Sci. Adv. 2:e1501499. doi: 10.1126/sciadv.1501499

Oliveira, C. D. D. P., and Araújo, J. F. (2021). Analysis of the agroecological zone method in predicting the impact of climate change on agriculture. Int. J. Adv. Res. Sci. Eng. Technol. 8. doi: 10.22161/ijaers.89.10

Orimoloye, I. R., Belle, J. A., and Ololade, O. O. (2021a). Drought disaster monitoring using MODIS derived index for drought years: a space-based information for ecosystems and environmental conservation. J. Environ. Manag. 284:112028. doi: 10.1016/j.jenvman.2021.112028

Orimoloye, I. R., Ololade, O. O., and Belle, J. A. (2021c). Satellite-based application in drought disaster assessment using terra MOD13Q1 data across free state province, South Africa. J. Environ. Manag. 285:112112. doi: 10.1016/j.jenvman.2021.112112

Orimoloye, I. R., Ololade, O. O., Mazinyo, S. P., Kalumba, A. M., Ekundayo, O. Y., Busayo, E. T., et al. (2019). Spatial assessment of drought severity in Cape Town area, South Africa. Heliyon 5:e02148. doi: 10.1016/j.heliyon.2019. e02148

Orimoloye, I. R., Olusola, A. O., Ololade, O., and Adelabu, S. (2021d). A persistent fact: reflections on drought severity evaluation over Nigerian Sahel using MOD13Q1. Arab. J. Geosci. 14, 1-18. doi: 10.1007/s12517-02108369-5
Orimoloye, I. R., Zhou, L., and and, M., Kalumba, A. M. (2021b). Drought disaster risk adaptation through ecosystem services-based solutions: way forward for South Africa. Sustainability 13:4132. doi: 10.3390/su13084132

Pienaar, L. O. U. W., and Boonzaaier, J. O. H. A. N. N. (2018). Drought Policy Brief Western Cape Agriculture. Elsenburg: Western Cape Department of Agriculture (WCDoA) and the Bureau for Food and Agricultural Policy (BFAP).

Piscitelli, L., Colovic, M., Aly, A., Hamze, M., Todorovic, M., Cantore, V., et al. (2021). Adaptive agricultural strategies for facing water deficit in sweet maize production: a case study of a semi-arid mediterranean region. Water 13:3285. doi: $10.3390 /$ w13223285

Purakayastha, T. J., Bera, T., Bhaduri, D., Sarkar, B., Mandal, S., Wade, P., et al. (2019). A review on biochar modulated soil condition improvements and nutrient dynamics concerning crop yields: pathways to climate change mitigation and global food security. Chemosphere 227, 345-365. doi: 10.1016/j.chemosphere.2019.03.170

Ropo, O. I., Perez, M. S., Werner, N., and Enoch, T. I. (2017). Climate variability and heat stress index have increasing potential ill-health and environmental impacts in the East London, South Africa. Int. J. Appl. Eng. Res. 12, 6910-6918.

Salami, S. O., Adegbaju, O. D., Idris, O. A., Jimoh, M. O., Olatunji, T. L., Omonona, S., et al. (2021). South African wild fruits and vegetables under a changing climate: the implications on health and economy. South African J. Bot. doi: $10.1016 /$ j.sajb.2021.08.038

Savari, M., Eskandari Damaneh, H., and Damaneh, H. E. (2021). Factors influencing farmers' management behaviors toward coping with drought: evidence from Iran. J. Environ. Plan. Manag. 64, 2021-2046. doi: 10.1080/09640568.2020.1855128

Schiermeier, Q. (2013). Climate models fail to 'predict'US droughts. Nat. News 496:284. doi: $10.1038 / 496284 a$

Sundaresan, J., Santosh, K. M., Déri, A., Roggema, R., and Singh, R. (2014). Geospatial Technologies and Climate Change. Cham: Springer International Publishing. doi: 10.1007/978-3-319-01689-4

Tembile, S. (2021). South Africa: Worst in 100 Years - Drought in All Three Cape Provinces Declared a National Disaster. Available online at: https://allafrica. com/stories/202107220210.html (accessed June 2021).

Yaseen, Z. M., and Shahid, S. (2021). Drought index prediction using data intelligent analytic models: a review. Intelligent Data Analytics for Decision-Support Systems in Hazard Mitigation 2021, 1-27. doi: 10.1007/978-981-15-5772-9_1

Conflict of Interest: The author declares that the research was conducted in the absence of any commercial or financial relationships that could be construed as a potential conflict of interest.

Publisher's Note: All claims expressed in this article are solely those of the authors and do not necessarily represent those of their affiliated organizations, or those of the publisher, the editors and the reviewers. Any product that may be evaluated in this article, or claim that may be made by its manufacturer, is not guaranteed or endorsed by the publisher.

Copyright (c) 2022 Orimoloye. This is an open-access article distributed under the terms of the Creative Commons Attribution License (CC BY). The use, distribution or reproduction in other forums is permitted, provided the original author(s) and the copyright owner(s) are credited and that the original publication in this journal is cited, in accordance with accepted academic practice. No use, distribution or reproduction is permitted which does not comply with these terms. 